Research Note

\title{
Long-Term Livestock Exclusion in an Arid Grassland Alters Vegetation and Soil
}

\author{
Ginger R. H. Allington ${ }^{1}$ and Thomas J. Valone ${ }^{2}$ \\ Authors are ${ }^{1}$ Graduate Student and ${ }^{2}$ Professor, Department of Biology, Saint Louis University, 3507 Laclede Avenue, St Louis, MO 63103, USA.
}

\begin{abstract}
Changes in soil and vegetation due to livestock grazing are occurring in arid lands throughout the world. The most extreme cases result in desertification, which is seen as largely irreversible, because of altered soil properties. To understand better how long-term livestock removal affects soil properties and vegetation, we compared water-infiltration rates, soil bulk density, and perennial grass cover inside and outside a long-term livestock exclosure in an arid grassland site in southeastern Arizona, United States. The site had not been desertified at the time of this study. Exclusion of livestock for 40 yr was associated with lower bulk density and higher water infiltration in both the dry and wet seasons. Perennial grass cover was higher and two native grasses, Eragrostis intermedia and Bouteloua hirsuta were significantly more common $(P<0.05)$ in the ungrazed area. These findings parallel our results from a desertified site and suggest that changes in soil physical properties associated with long-term livestock removal are not an artifact of desertification and can take place in a system that has remained in a grassland state. Our data suggest that, although significant changes in species composition have occurred, this grassland is relatively resilient to substantial changes in soil physical properties.
\end{abstract}

\section{Resumen}

Cambios en el suelo y la vegetación debidos al pastoreo del ganado están ocurriendo en tierras áridas de todo el mundo. Los casos más extremos resultan en desertificación, que es visto mayormente como un proceso irreversible, debido a la alteración de las propiedades del suelo. A fin de mejorar la comprensión de cómo la exclusión de largo plazo del ganado afecta las propiedades del suelo y la vegetación, comparamos las tasas de infiltración de agua, la densidad aparente del suelo, y la cobertura de pastos perennes dentro y fuera de clausuras de pastoreo en un sitio de pastizal árido en el sudeste de Arizona, EE.UU. El sitio no había sido desertificado en el momento de realizar este estudio. La exclusión del pastoreo por cuarenta años estuvo asociada con una menor densidad aparente del suelo y una mayor tasa de infiltración de agua tanto en la estación seca como en la estación húmeda. La cobertura de pastos perennes fue más alta y dos pastos nativos, Eragrostis intermedia y Bouteloua hirsuta fueron significativamente más comunes $(P<0.05)$ en la zona no pastoreada. Se encontró un paralelismo entre estos datos y los resultados de un sitio desertificado que sugieren que los cambios en las propiedades físicas del suelo asociados a una clausura de pastoreo de largo plazo no son un artefacto de la desertificación y pueden ocurrir en un sistema que ha permanecido en un estado graminoso. Nuestros datos sugieren que, si bien han ocurrido cambios significativos en la composición de especies, este pastizal es relativamente resiliente a cambios sustanciales en las propiedades físicas del suelo.

Key Words: bulk density, desertification, infiltration, perennial grass, rangeland

\section{INTRODUCTION}

Desertification, the loss of productivity in arid grasslands, is occurring throughout the world (Reynolds et al. 2007). Desertification often involves a change in vegetation from dominance of perennial grasses to dominance by shrubs and bare ground. This shift has been attributed to climate change, altered fire regimes, and overgrazing; livestock herbivory has been suggested to be the most important factor driving this change (Schlesinger et al. 1990). The conversion to shrublands has persisted, even in cases where livestock have been removed for over two decades (Schlesinger et al. 1990). This persistence of shrublands forms the basis for theories that desertification is irreversible, a new stable state in arid systems (Bestelmeyer and Herrick 2004).

\footnotetext{
This research was funded by the Research Ranch Foundation and Wells Fargo.

Correspondence: Ginger Allington, Dept of Biology, Saint Louis University, 3507 Laclede Ave, St Louis, MO 63103, USA. Email: galling@@slu.edu

Manuscript received 18 June 2010; manuscript accepted 12 February 2011.
}

Recently, perennial grass recovery has been reported at four desertified sites (Fuhlendorf et al. 2001; Rasmussen et al. 2001; Valone et al. 2002; Zhang et al. 2005). Castellano and Valone (2007) proposed a novel mechanism to explain these reversals. They postulate that in the absence of livestock and with the cessation of trampling, soil compaction decreases slowly over time, resulting in increased water infiltration into the soil. Because water strongly limits plant growth in arid systems (van de Koppel and Rietkerk 2004), an increase in soil water availability via this mechanism is presumed to eventually create an environment conducive to perennial grass recovery (Castellano and Valone 2007).

To evaluate this hypothesis, both Castellano and Valone (2007) and Allington and Valone (2010) collected data from several long-term livestock exclosures in desertified habitat. At all sites, water-infiltration rates were higher, and soil compaction was lower, in areas protected from livestock compared to grazed areas. These differences were greatest at the site with the 
longest history of grazing exclusion (nearly $50 \mathrm{yr}$ ), where perennial grasses have begun to recover (Valone et al. 2002; Castellano and Valone 2007; Allington and Valone 2010).

However, all of the sites evaluated by Castellano and Valone (2007) and Allington and Valone (2010) were desertified. In order to attribute these soil changes to livestock exclusion more reliably, these patterns needed to be evaluated at additional, nondesertified sites with long-term livestock removal. Further, the data were collected only when soils were dry (Castellano and Valone 2007; Allington and Valone 2010). Seasonal variation in soil moisture can affect relative rates of water infiltration (Rostagno 1989) and could alter detected differences between grazed and ungrazed soils.

To address these issues, we collected water infiltration, soil compaction, and vegetation data at the Appleton-Whittell Research Ranch, a large grazing exclosure established in 1968. Grazing by cattle has continued on adjacent ranches, but the region has not experienced widespread desertification and the entire area is still primarily grassland, although differences in grass composition and abundance have been documented (Bock et al. 1984; Bock and Bock 1993). We collected data during dry soil conditions (late June) and moist conditions after summer rains (early August) to examine seasonal differences in relative infiltration rates.

\section{METHODS}

\section{Study Area}

The Appleton-Whittell Research Ranch (Research Ranch) is located in the Sonoita Valley in southeastern Arizona, United States. The 3160 -ha property is comprised of a series of mesas and drainages that form wide shallow draws. The vegetation on the mesas is primarily grassland, characterized as Madrean mixed-grass prairie (McLaughlin et al. 2001). Dominant grasses are primarily native $\mathrm{C}_{4}$ perennial bunchgrasses in the genera: Bouteloua, Aristida, and Eragrostis. Two exotic grasses, Lehmann lovegrass (Eragrostis lehmanniana Nees) and Boer's lovegrass (Eragrostis curvula [Schrad] Nees var. conferta Stapf.) are common and spreading rapidly (Bock et al. 2007a). Shrub cover on the mesas is sparse, dominated primarily by velvet mesquite (Prosopis velutina West.). Nomenclature herein primarily follows Kearney and Peebles (1960), with some updates, as noted by McLaughlin et al. (2001).

This study was performed on top of a mesa along the eastern boundary of the property where a fenceline separates the Research Ranch (ungrazed) from actively grazed lands of the Diamond C ranch. The Diamond C ranch has been subject to short-duration rotational grazing for decades, following the practices of holistic resource management (Savory 1983). Stocking density and rotation times vary annually, but average one animal unit per 13 hectares and a grazing duration of less than 1 wk per 50 -ha paddock (Bock et al. 2007a). The grazed and ungrazed areas are adjacent, on a level mesa top with gravelly loam soils of the White House series (Breckenfeld and Robinett 2001). All transects started at least $15 \mathrm{~m}$ from the fence, in order to avoid areas potentially disturbed during routine fence inspection and repair; there is no road along the fence.

The entire area (grazed and ungrazed) burned in a wildfire in 2002 (Bock et al. 2007b).

\section{Water Infiltration}

Water infiltration was measured along 18 pairs of transects on opposite sides of the fence line. Paired grazed-ungrazed transects were laid out perpendicular to, and on opposite sides of, the fence (Fig. S1, available online at http://dx.doi.org/10.2111/ REM-D-10-00098.s1). Transects were parallel to each other, separated by at least $5 \mathrm{~m}$. Water infiltration was recorded with an IN2-W Turf-Tec double-ring infiltrometer (Castellano and Valone 2007). We took measurements in June 2008, prior to the summer rainy season while the soil was dry, and in August 2008, when the soil was receiving nearly daily precipitation.

Readings were taken after $7.5 \mathrm{~min}$ at six, 5 -m intervals along each transect $(n=12$ transects in June and $n=18$ transects in August). Readings were collected on the first six transects at $10 \mathrm{~min}$, but the infiltrometers ran out of water before the time was finished. We changed the reading to $7.5 \mathrm{~min}$ for the remainder of the transects and the original 10-min data were discarded, hence the discrepancy in transect number between June and August. All readings were taken on patches of bare ground and data from all cross-fence pairs were collected on the same day. Data from the six locations along each transect were averaged to produce a single value per transect, which were compared with paired $t$ tests.

\section{Soil Bulk Density}

Soil samples were collected on each side of the fence in June 2008 along two parallel $100-\mathrm{m}$ transects located approximately $15 \mathrm{~m}$ from, and on opposite sides of, the fence (Fig. S1). At each sampling location, paired soil samples were collected: one from under a mesquite shrub (Prosopis velutina) canopy $(n=10)$ and one from bare ground $1 \mathrm{~m}$ north of each shrub $(n=10)$. For each location, bulk density was obtained from the mean of three subsamples. Samples of fixed volume $\left(90.1 \mathrm{~cm}^{3}\right)$ were collected with a slide hammer from the top $5 \mathrm{~cm}$ of soil (Baize 1993). Samples were dried, weighed, and sieved to $2 \mathrm{~mm}$ to correct for the volume and weight of the rocks (Laycock and Conrad 1967). Mean grazed vs. ungrazed bulk density values were compared with Student's $t$ tests, and between paired shrub-bare ground samples with paired $t$ tests.

\section{Vegetation}

Vegetation data were collected in August when the grasses had mature seed heads. We measured basal cover of perennial grasses and canopy cover of shrubs. Fifteen paired $25-\mathrm{m}$ transects were established perpendicular to, and on opposite sides of, the fence (Fig. S1). Transects started at least $15 \mathrm{~m}$ from the fence line and were separated by at least $5 \mathrm{~m}$. Transect intercepts of basal perennial grass cover were recorded every $10 \mathrm{~cm}$ for a total of $n=250$ points per transect. Percent cover of individual species and the total cover by transect exhibited nonhomogeneous variances and were thus compared with the nonparametric Wilcoxon matched-pairs tests.

\section{RESULTS}

\section{Water Infiltration}

Water infiltration was higher in June, when soils were dry, than in August (Fig. 1). On the ungrazed side of the fence, 


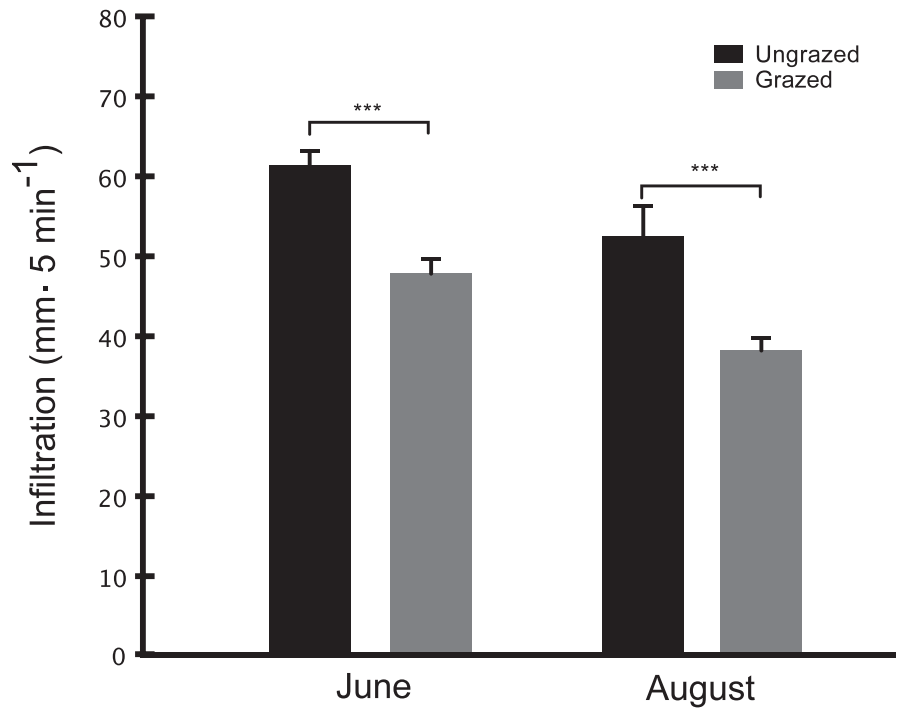

Figure 1. Mean water infiltration rate $\left(\mathrm{mm} \cdot 5 \mathrm{~min}^{-1}\right)$ in ungrazed (black) and grazed (grey) transects in June and August at the Appleton Whittell Research Ranch, near Sonoita, Arizona. Vertical lines represent one standard error. ${ }^{* * *} P<0.001$.

infiltration rates were approximately $17 \%$ higher in June than August, and the difference was even more dramatic in the grazed area: Rates differed by over $25 \%$ between June and August. Ungrazed soils had significantly higher infiltration rates than grazed soils, regardless of soil moisture (Fig. 1).

\section{Soil Bulk Density}

Bulk density from bare-ground locations was $5.5 \%$ higher in samples taken from grazed locations compared to ungrazed (Fig. 2). Bulk density under mesquite shrub canopy was significantly higher $(7.3 \%)$ in the grazed area compared the ungrazed area (Fig. 2). Undershrub soil bulk density values were not significantly different from bare-ground values in the ungrazed or grazed areas (Fig. 2).

\section{Vegetation}

Ten species of perennial grass and five species of shrub were present on the transects (Table 1). Total basal perennial grass cover was significantly higher on the ungrazed transects $(P<0.001$; Table 1$)$, whereas shrub cover was low $(<9 \%$; Table 1) and did not differ between grazed and ungrazed transects. Plains lovegrass (Eragrostis intermedia Hitchc.), and hairy grama (Bouteloua hirsuta Lag.) both had significantly higher cover in the ungrazed transects (Table 1). Sideoats grama (Bouteloua curtipendula [Michx.] Torr.), cane bluestem (Bothriochloa barbinodis [Lag.] Herter), and wolfstail (Lycurus phleoides Kunth) were only found in the ungrazed transects (Table 1).

The shrubs prairie acacia (Acacia angustissima [P. Miller] var. suffretescens [Rose] Isley) and burroweed (Isocoma tenuisecta Greene) had significantly higher cover on the ungrazed transects, and catclaw mimosa (Mimosa aculeaticarpa Ortega var. biuncifera [Bentham] Barneby) was only found on the ungrazed side of the fence (Table 1).

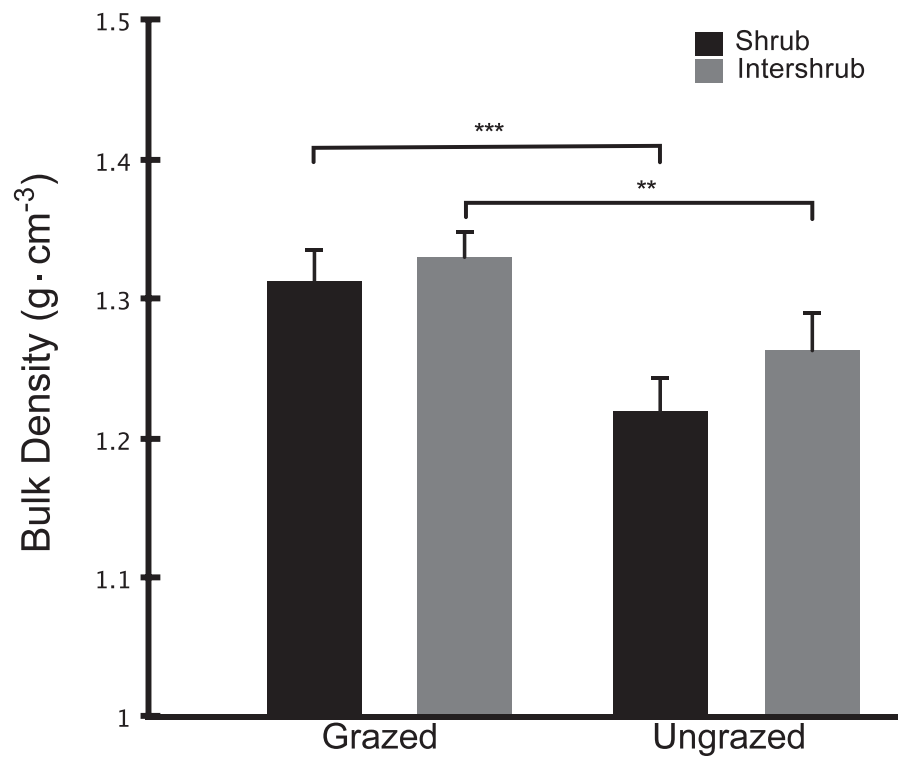

Figure 2. Mean soil bulk density $\left(\mathrm{g} \cdot \mathrm{cm}^{-3}\right)$ under shrub canopies (black) and bare ground intershrub locations (gray), on grazed and ungrazed sides of the livestock exclosure at the Appleton Whittell Research Ranch, near Sonoita, Arizona. There was no significant difference between shrub-intershrub values in grazed $(P<0.29)$ or ungrazed soils $(P<0.11)$. Samples from grazed soils had significantly higher compaction than ungrazed soils both under shrubs $(P<0.0001)$ and in intershrub bare ground $(P<0.01)$. Vertical lines represent one standard error.

\section{DISCUSSION}

At a 40-yr livestock exclosure in a nondesertified arid grassland, soil compaction was lower, whereas water infiltration and vegetation cover were higher in the ungrazed area compared to grazed area. These patterns are similar to those found at long-term livestock exclosures in desertified habitats and so it is unlikely that our earlier findings were an artifact of desertification. We acknowledge that the present data come from only one site, which limits our ability to generalize the results. Long-term (i.e., greater than $30 \mathrm{yr}$ ) grazing exclosures in nondesertified arid grassland habitat are rare, but are required to document the effect of livestock removal on soil properties further.

Livestock trampling is known to compact soil (Thurow et al. 1988). Thus, it is not surprising that we found higher compaction in the grazed area. In the absence of livestock, soil compaction is lessened by repeated wet-dry and freezethaw cycles (Mapfumo et al. 1999) that lead to the accumulation of soil aggregates (Steffens et al. 2008), which affect water infiltration rates (Russell et al. 2001). Thus differences in compaction likely explain the observed cross fence differences in water infiltration. While the presence of vegetation can positively influence water infiltration as assumed in many theoretical models (Rietkerk and van de Koppel 1997), our water infiltration data come from bareground locations between grass clumps: aboveground vegetation is not responsible for the cross-fence differences observed.

We found seasonal variability in water infiltration: rates were lower in late summer when soils were wet compared to dry June 
Table 1. Mean percent basal cover \pm standard error of perennial grasses and shrubs in ungrazed and grazed transects at the Appleton Whittell Research Ranch, near Sonoita, Arizona. Wilcoxon matched-pairs tests, $n=15$ transects. Some low-coverage species are not included in this table; means do not sum to total. Bold indicates significance at $P<0.05$.

\begin{tabular}{|c|c|c|c|}
\hline & Ungrazed (mean $\pm \mathrm{SE}$ ) & Grazed (mean $\pm \mathrm{SE}$ ) & $P<$ \\
\hline \multicolumn{4}{|l|}{ Grasses } \\
\hline Eragrostis curvula & $30.4 \pm 0.4$ & $23.4 \pm 1.8$ & 0.431 \\
\hline Eragrostis lehmanniana & $3.9 \pm 1.8$ & $3.4 \pm 0.9$ & 0.185 \\
\hline Eragrostis intermedia & $1.2 \pm 0.5$ & $0.0 \pm 0.0$ & 0.011 \\
\hline Aristida spp. & $1.1 \pm 0.6$ & $0.2 \pm 0.1$ & 0.980 \\
\hline Bouteloua gracilis & $2.2 \pm 0.8$ & $1.6 \pm 0.4$ & 0.827 \\
\hline Bouteloua hirsuta & $0.6 \pm 0.2$ & $0.1 \pm 0.1$ & 0.014 \\
\hline Bouteloua curtipendula & $0.1 \pm 0.1$ & $0.0 \pm 0.0$ & 0.351 \\
\hline Bouteloua chondrosioides & $0.2 \pm 0.2$ & $0.3 \pm 0.1$ & 0.737 \\
\hline Bothriochloa barbinodis & $0.11 \pm 0.1$ & $0.0 \pm 0.0$ & 0.164 \\
\hline Lycurus phleoides & $0.24 \pm 0.1$ & $0.0 \pm 0.0$ & 0.080 \\
\hline Total & $40.9 \pm 1.8$ & $30.0 \pm 1.7$ & 0.001 \\
\hline \multicolumn{4}{|l|}{ Shrubs } \\
\hline Prosopis velutina & $2.1 \pm 1.0$ & $4.7 \pm 2.3$ & 0.625 \\
\hline $\begin{array}{l}\text { Acacia angustissima } \\
\text { var. suffretescens }\end{array}$ & $2.8 \pm 1.0$ & $0.1 \pm 0.1$ & 0.008 \\
\hline Mimosa dysocarpa & $0.5 \pm 0.3$ & $0.2 \pm 0.1$ & 0.461 \\
\hline Isocoma tenuisectus & $2.8 \pm 0.6$ & $0.2 \pm 0.2$ & 0.003 \\
\hline Mimosa aculeaticarpa & $0.1 \pm 0.1$ & $0.0 \pm 0.0$ & 1.000 \\
\hline Total & $8.3 \pm 1.5$ & $5.2 \pm 2.2$ & 0.132 \\
\hline
\end{tabular}

soils. Complex relationships between soil moisture level and infiltration are expected. As soil moisture increases, infiltration is expected to lessen as soils reach field capacity (Rostagno 1989). Despite seasonal variation in infiltration rates, infiltration was higher in ungrazed soils during both sampling periods.

Eragrostis intermedia and Bouteloua hirsuta had significantly higher cover in the ungrazed area and B. barbinodis and B. curtipendula and L. phleoides were only present on ungrazed transects inside the fence (Table 1). Such differences resulted in higher basal cover and greater grass species richness on ungrazed transects, and are consistent with results from previous studies at the Research Ranch (Bock et al. 1984; Bock and Bock 1993) as well as our data from a recovering desertified site (Allington and Valone 2010).

Two exotic species, Boer's lovegrass (Eragrostis curvula) and Lehmann lovegrass (Eragrostis lehmanniana), dominated the study area (Table 1). We found no difference in basal cover of these species across the grazing fence. Our results contrast with Bock et al. (2007a), who found higher cover of exotics in grazed versus ungrazed sites at the Research ranch. This difference likely stems from the fact that Bock et al. (2007a) worked near areas where these exotics had been seeded the 1950s, whereas our transects were located away from the seeded area.

\section{IMPLICATIONS}

Long-term exclusion of livestock can result in significant differences in soil physical properties in desertified sites (Castellano and Valone 2007; Allington and Valone 2010) and our work shows that such patterns also occur in a region that has not been desertified. It is important to note that this region has not undergone a shift toward a shrubland state (Scheffer et al. 2001), despite the fact that soil compaction was $5.5-7.3 \%$ higher, water infiltration rates were $17-25 \%$ lower, and grass cover was $36 \%$ lower in the grazed area. This implies that this arid grassland is relatively stable against substantial changes in compaction and infiltration. Thus, arid grasslands can be maintained under grazing despite significant changes in soil hydrologic properties. However, there were important cross-fence differences in perennial grasses at this site. The grazed area had lower grass cover and fewer species compared to the area across the fence that had not been grazed in over 40 yr. Such differences can affect both biodiversity and livestock production (Bock et al. 1984; DiTomaso 2000). Long-term livestock exclusions provide a unique opportunity to examine the changes in soil properties and vegetation that occur over time in the absence of livestock.

\section{ACKNOWLEDGMENTS}

We thank R. Jelks for permission to work on the Diamond C ranch and L. Kennedy and C. Haas for assistance at the Appleton-Whittell Research Ranch. We also thank two reviewers for insightful comments on a previous version of the manuscript.

\section{LITERATURE CITED}

Allington, G. R. H., and T. J. Valone. 2010. Reversal of desertification: the role of physical and chemical soil properties. Journal of Arid Environments 74:973-977.

BAIzE, D. 1993. Soil science analyses: a guide to current use. Chichester, England: John Wiley and Sons. 192 p. 
Bestelmeyer, B. T., and J. E. Herrick. 2004. Land management in the American Southwest: a state-and-transition approach to ecosystem complexity. Environmental Management 34:38-51.

Bock, C., J. Bock, L. KennedY, AND Z. Jones. 2007a. Spread of non-native grasses into grazed versus ungrazed desert grasslands. Journal of Arid Environments 71:229-235.

Bock, C. E., AND J. H. Bock. 1993. Cover of perennial grasses in southeastern Arizona in relation to livestock grazing. Conservation Biology 7:371-377.

Bock, C. E., J. H. Bock, W. R. Kenney, and V. M. Hawthorne. 1984. Responses of birds, rodents and vegetation to livestock exlcosures in a semi-desert grassland site. Journal of Range Management 37:239-242.

Bock, C. E., L. KennedY, J. H. Bock, And Z. F. Jones. 2007b. Effects of fire frequency and intensity on velvet mesquite in an Arizona grassland. Rangeland Ecology \& Management 60:508-514.

BRECKENFELD, D., AND D. Robinett. 2001. Soil and range resource inventory of the National Audubon Society Appleton-Whittell Research Ranch, Santa Cruz County, Arizona. Washington, DC, USA: US Department of Agriculture, Natural Resources Conservation Service. 61 p.

Castellano, M. J., and T. J. Valone. 2007. Livestock, soil compaction and water infiltration rate: evaluating a potential desertification recovery mechanism. Journal of Arid Environments 71:97-108.

DITomaso, J. M. 2000. Invasive weeds in rangelands: species, impacts, and management. Weed Science 48:255-265.

Funlendorf, S. D., D. D. Briske, and F. E. Smeins. 2001. Herbaceous vegetation change in variable rangeland environments: the relative contribution of grazing and climatic variability. Applied Vegetation Science 4:177-188.

Kearney, T. H., and R. H. Peebles. 1960. Arizona flora. Berkeley, CA, USA: University of California Press. 1085 p.

Laycock, W. A., and P. W. Conrad. 1967. Effect of grazing on soil compaction as measured by bulk density on a high elevation cattle range. Journal of Range Management 20:136-140.

Mapfumo, E., D. Chanasyk, M. Naeth, and V. Baron. 1999. Soil compaction under grazing of annual and perennial forages. Canadian Journal of Soil Science 79:191-199.

Mclaughilin, S., E. Geiger, and J. Bowers. 2001. A flora of the Appleton-Whittell Research Ranch, Northeastern Santa Cruz County, Arizona. Journal of the Arizona-Nevada Academy of Science 33:113-131.
Rasmussen, K., B. Fog, and J. E. Madsen. 2001. Desertification in reverse? Observations from northern Burkina Faso. Global Environmental Change 11:271-282

Reynolds, J. F., D. M. Stafford Smith, E. F. Lambin, B. L. Turner II, M. Mortimore, S. P. J. Batterbury, T. E. Downing, H. Dowlatabadi, R. J. Fernandez, J. E. Herrick, E. Huber-Sannwald, H. Jiang, R. Leemans, T. Lynam, F. T. Maestre, M. Ayarza, and B. WALKER. 2007. Global desertification: building a science for dryland development. Science 316:847-851.

RietKerk, M., AND J. van de Koppel. 1997. Alternate stable states and threshold effects in semi-arid grazing systems. Oikos 79:69-76.

Rostagno, C. 1989. Infiltration and sediment production as affected by soil surface conditions in a shrubland of Patagonia, Argentina. Journal of Range Management 42:382-385.

Russell, J. R., K. Betteridge, D. A. Costall, and A. D. MacKay. 2001. Cattle treading effects on sediment loss and water infiltration. Journal of Range Management $54: 184-190$

SAVORY, A. 1983. The Savory grazing method or holistic resource management. Rangelands 5:155-159.

Scheffer, M., S. Carpenter, J. A. Foley, and A. Folke. 2001. Catastrophic shifts in ecosystems. Nature 413:591-596.

Schlesinger, W. H., J. F. Reynolds, G. L. Cunningham, L. F. Huenneke, W. M. Jarrell, R. A. Virginia, and W. G. Whitford. 1990. Biological feedbacks in global desertification. Science 247:1043-1048.

Steffens, M., A. Kolbl, K. U. Totsche, and I. Kogel-Knaber. 2008. Grazing effects on soil chemistry and physical properties in a semiarid steppe of Inner Mongolia (P.R. China). Geoderma 143:63-72.

Thurow, T. L., W. H. BlackBurn, and C. A. Taylor, JR. 1988. Infiltration and intertill erosion responses to selected livestock grazing strategies, Edwards Plateau, Texas. Journal of Range Management 41:296-302.

Valone, T. J., M. Meyer, J. H. Brown, and R. M. Chew. 2002. Timescale of perennial grass recovery in a desertified arid grasslands following livestock removal. Conservation Biology 16:995-1002.

van de Koppel, J., And M. RietKerk. 2004. Spatial interactions and resilience in arid ecosystems. The American Naturalist 163:113-121.

Zhang, J. Y., Y. Wang, X. Zhao, G. Xie, and T. Zhang. 2005. Grassland recovery by protection from grazing in a semi-arid sandy region of northern China. New Zealand Journal of Agricultural Research 48:277-284. 